УДК $82(091)$

DOI 10.22455/2541-7894-2018-4-148-162

\title{
Нина МОРО3
}

\section{«ДЕРЕВО ЖЕЛАНИЙ»: ЭКСПЕРИМЕНТ У. ФОЛКНЕРА В ЖАНРЕ ПОВЕСТИ ДЛЯ ДЕТЕЙ}

Аннотация: Статья посвящена единственному детскому произведению У. Фолкнера - повести «Дерево желаний» (“The Wishing Tree”), написанной в 1927 году для будущей приемной дочери Виктории Франклин. Повесть была опубликована в 1967 г. и представляет интерес как сама по себе, так и в контексте творчества Фолкнера второй половины 1920-х годов, тем более что детские образы зачастую оказываются на пересечении главных силовых линий фолкнеровских романов. Фолкнер учитывает конвенции детской литературы и вводит в повесть дидактические элементы. При этом «Дерево желаний» предваряет главное фолкнеровское произведение 1920-х годов - роман «Шум и ярость», предлагая «детские» вариации модернистских мотивов относительности времени и памяти; здесь же можно обнаружить и элементы зарождающегося «южного мифа». Кроме того, Фолкнер сближает интуитивное детское мышление и мышление взрослого «примитива». В произведении, предназначенном для ребенка, Фолкнер экспериментирует с детской речью и остранением, расширяя возможности модернистского письма. При этом Фолкнер помещает действие своей детской повести в аллегорико-фантастическое пространство. Приключения детей разворачиваются в мире вербализованных желаний, оживающих слов. «Дерево желаний» отсылает не только к «Алисе в стране чудес», но и к драмам М. Метерлинка и популярным в первые десятилетия XX века романам Дж. Б. Кейбелла. Особый интерес представляют переклички между детской повестью Фолкнера и другим его полузабытым произведением середины 1920-х гг. - повестью «Майский день» (“Мауday”, 1926).

Ключевые слова: Уильям Фолкнер, детская литература, детское сознание, модернизм, фантастическое, аллегория, дидактизм.

(C) 2018 Нина Анатольевна Мороз (кандидат филол. наук, преподаватель, Московский государственный университет М. В. Ломоносова) nina.a.moroz@gmail. com 
UDC 82(091)

DOI 10.22455/2541-7894-2018-4-148-162

\section{Nina MOROZ}

\section{“THE WISHING TREE": WILLIAM FAULKNER'S ONLY EXPERIMENT IN CHILDREN'S FICTION}

Abstract: This paper is concerned with "The Wishing Tree", the only children's story known to have been created by William Faulkner. It was written in 1927 for Faulkner's future stepdaughter Victoria Franklin and published in 1967. Though it has been seen as a marginal part of Faulkner's work, "The Wishing Tree" provides an aid in interpreting his major themes. It should be studied together with Faulkner's modernist novels and stories of the late 1920 s, especially taking into consideration Faulkner's deep interest in children's consciousness. Faulkner pays respect to the conventions of children's literature, so the story includes didactic elements. At the same time, in "The Wishing Tree" Faulkner experiments with estrangement techniques and introduces several motives particularly important in "The Sound and the Fury", e.g. desire and the relativity of time and memory. Moreover, in "The Wishing Tree" Faulkner juxtaposes the intuitive thinking of a child and of an adult "primitive". Faulkner's children's story is a quest, taking place in the allegorical space in which wishes are instantly verbalized and words become flesh. The dreamlike nature of the plot provides parallels with "Alice in Wonderland", yet the whole range of allusions is rather peculiar: Maeterlinck's symbolist dramas, James Branch Cabell's fantasy novels, etc. The paper also investigates the parallels between "The Wishing Tree" and "Mayday" (1926), another example of young Faulkner's "fantasy fiction", a "fable" about a young knight's quest for love.

Keywords: William Faulkner, children's literature, children's consciousness, modernism, fantasy, allegory, didacticism.

(C) 2018 Nina A. Moroz (PhD, Assistant Professor, Lomonosov Moscow State University, Russia)nina.a.moroz@gmail.com 
Повесть «Дерево желаний» (“The Wishing Tree”) - единственное произведение, написанное У. Фолкнером для детской аудитории. Повесть была опубликована почти через пять лет после смерти Фолкнера - 8 апреля 1967 г. в "Saturday Evening Post", и несколько дней спустя вышла отдельным изданием в издательстве "Random House" (сначала в коллекционном варианте, а вскоре и в формате, предназначенном для массовой продажи; книгу иллюстрировал Дон Болоньезе) ${ }^{1}$. Повесть была создана за 40 лет до выхода книги: 5 февраля 1927 г. Фолкнер подарил отпечатанную на цветной бумаге и собственноручно сброшюрованную книжечку Виктории Франклин, дочери Эстелл Олдхэм-Франклин от первого брака и своей будущей приемной дочери (Фолкнер и Эстелл заключат брак 20 июня 1929 г.). Повесть имеет посвящение: "To Victoria"; девочка получила книгу в качестве подарка на свой восьмой день рождения. В описании семейства главной героини «Дерева желаний», девочки Далси (Dulcie), можно увидеть закономерное сходство с семьей Виктории: у Далси есть младший брат Дики (брат Виктории, Мэлколм Франклин, был младше на четыре года); мать Далси очень красива, но у нее «серьезные и несчастливые глаза» (grave unhappy eyes, $81^{2}$ ) - причины «несчастья» не прояснены, но они, очевидно, должны были быть понятны читателю; отец в повести не появляется (Эстелл рассталась с первым мужем, Корнеллом Франклином, в 1926 г.). Логично предположить, что «Дерево желаний» адресовано не только восьмилетней Виктории, но и ее матери, которая должна была читать книгу вместе с дочерью. Литературный подарок Фолкнера - еще и часть его стратегии ухаживания за Эстелл, утраченной возлюбленной, которая несколько лет назад предпочла другого.

Именно самодельная книжечка, подаренная Виктории, послужила основой для публикации 1967 г. Об этом упоминается в «Примечании издателя»: «До появления этого издания существовала только одна копия книги. [...] Есть другая, чуть более длинная версия этого рассказа, очевидно, ранний черновик, и несколько его машинописных копий. Издание "Random House" опирается на подлинник, созданный Фолкнером через год после выхода его первого романа...» (85). Здесь следует сделать оговорку, важную не только для решения текстологических за-

1 Faulkner, W. The Wishing Tree, ill. by Don Bolognese. N.Y.: Random House, 1967. Повесть переведена на русский язык: Фолкнер У. Дерево, которое исполняет желания / Пер. И. Павлычевой. СПб.: Лицей, 2001. Ирина Павлычева также написала по мотивам повести Фолкнера одноименную пьесу для детского театра.

2 Повесть «Дерево желаний» с указанием соответствующих страниц в скобках цитируется по изданию: Faulkner, W. The Wishing Tree. N.Y.: Random House, 1967. 
дач, но и для интерпретации повести. В феврале того же 1927 года (на несколько дней раньше или позже дня рождения Виктории, но не позже 11 февраля) Фолкнер подарил еще один машинописный экземпляр повести другой девочке - Маргарет Браун с посвящением: “То Margaret Brown from her friend, Bill Faulkner"'. Единственное отличие, кроме посвящения, - дефис в названии: “The Wishing-Tree”. 11 февраля отец Маргарет, Кэлвин Браун сделал в дневнике запись о том, что прочел книгу, которую Фолкнер специально написал для Маргарет и подарил ей на днях ${ }^{4}$. Спустя 20 лет Фолкнер подарит свою повесть еще двум детям $^{5}$ (причем каждый из адресатов будет считать себя единственным).

Особый интерес представляет фигура Маргарет Браун, которая, учитывая хронологию, была если и не равноправным с Викторией, то вторым главным адресатом повести «Дерево желаний». Много лет спустя Фолкнер вспоминал, что его подарок был «проявлением жалости и сострадания по отношению к обреченному ребенку» ${ }^{6}$. Действительно, Маргарет была неизлечимо больна раком и умерла спустя полгода после получения книги. Непосредственные упоминания болезни в повести немногочисленны, но они есть - например, образ матери складывается из двух эскизных характеристик: «серьезные несчастливые глаза» и нежные руки, которые ухаживают за Далси, когда та больна. Так или иначе, повесть «Дерево желаний» изначально адресована двум детям - дочери возлюбленной (которую Фолкнер пытается вернуть) и дочери друзей, умирающей от неизлечимой болезни. Как нам кажется, это обстоятельство имеет важные следствия.

Повесть «Дерево желаний» представляет собой квест - путешествие-испытание, по итогам которого героиня получает моральный урок: Фолкнер учитывает конвенции детской литературы и вводит в повесть дидактические элементы. Квест разворачивается в фантастическом пространстве грезы или «сна во сне»: повествование открывается эпизодом пробуждения Далси в день рождения. Далси путешествует с друзьями и мальчиком-волшебником по имени Морис; приключения

3 Brodsky, L.D. William Faulkner, Life Glimpses. Austin: University of Texas Press, 1990: 184.

4 Подробнее см.: Brodsky, L.D. William Faulkner, Life Glimpses: 183-187.

5 Очевидно, у Фолкнера не осталось черновиков, поэтому в 1948 году он под благовидным предлогом одолжил экземпляр у Браунов и изготовил две машинописные копии - подарки на Рождество для Филипа Стоуна-младшего и Шелли Форд.

6 “To Harold Ober, 4 Feb. 1959." Selected Letters of William Faulkner, ed. by Joseph Blotner. New York: Random House, 1976: 421. 
завершаются вторичным пробуждением Далси, возвращающим ее в реальность. Морис, появляющийся из ниоткуда, предлагает Далси отправиться на поиски Дерева желаний. К Далси и Морису присоединяются младший брат Далси Дики, ее приятель Джордж, темнокожая няня Элис, а позже - старик Эгберт и Исход (Exodus), муж Элис ${ }^{7}$. Морис - обладатель волшебной сумки для книг, в которую помещаются предметы любых размеров - от лестницы до шотландского пони. Путешественники вскоре обнаруживают дерево с белыми листьями, которые оказываются разноцветными ${ }^{8}$, если их сорвать. Листья исполняют желания, но счастья это не приносит ни девочке, ни ее спутникам: Джордж объедается шоколадным тортом, всей компании приходится спасаться от льва, которого неосторожно воображает тот же Джордж, Дики наказан за желание причинить боль живому существу и т.д. Примечательно, что сама Далси не испытывает неправедных желаний, но переживает последствия чужого легкомыслия вместе со своими спутниками.

В конечной точке пути обнаруживается еще одно дерево, покрытое разноцветными листьями; приблизившись, дети понимают, что это человек, на руках и плечах которого сидят птицы с оперением разных цветов. Его имя знает Морис - это святой Франциск Ассизский (Good Saint Francis), проповедовавший птицам. Финал повести обретает отчетливо дидактическую окраску. Речь святого Франциска, обращенная к детям, - это проповедь; он объясняет, что срывать листья с Дерева желаний не стоит, так как иначе оно быстро утратит всю листву. Здесь окончательно проясняются и без того явственные параллели с образами райского древа и запретного плода. Правда, сон-приключение демонстрирует лишь возможность грехопадения. Далси проходит своеобразную инициацию и получает моральный урок, не согрешив, на ее пути вовремя оказывается второе дерево - и добрый советчик. Положение древа-Франциска у реки также важно: в дидактическом измерении это праведник первого псалма - «дерево, посаженное при потоках вод, которое приносит плод свой вовремя и лист которого не вянет» (Пс. 1:3). Правда, этот образ получает дополнительное измерение, если учесть

\footnotetext{
7 Изображение Элис и Исхода во многом предвосхищает тему «черной арлекинады» в позднейшем творчестве Фолкнера. Джон Дицки считает, что детская повесть 1927 года - одно из первых произведений, в которых Фолкнер открывает потенциал темы американского Юга. См.: Ditsky, J. "William Faulkner's 'The Wishing Tree': Maturity's First Draft.” The Lion and the Unicorn 2:1 (1978): 59.

8 Возможно, именно поэтому первые экземпляры повести Фолкнер отпечатал на цветной бумаге.
} 
специфический контекст раннего творчества Фолкнера (мы обратимся к нему ниже).

В обмен на листья Святой Франциск дарит Далси и ее спутникам по птице. Подарок сопровождается моральным напутствием и рассуждением о том, как научиться избегать неправедных желаний: «Если вы будете кормить ее [птицу] и заботиться о ней, вы никогда не будете испытывать эгоистичных желаний, потому что люди, которые оберегают беззащитных и заботятся о них, не могут иметь эгоистичных желаний» (77). Далси получает птицу с синими перьями и, пробуждаясь, возвращается в реальность. Синяя птица в клетке ждет ее у постели - это материнский подарок на день рождения.

В публикациях, посвященных «Дереву желаний» (достаточно немногочисленных), упоминаются два главных литературных источника тем и образов повести - «Алиса в Стране чудес» Л. Кэрролла и «Синяя птица» М. Метерлинка. Параллели с «Синей птицей» - феерией о странствиях детей в поисках счастья - очевидны, хотя символическая структура драмы Метерлинка гораздо сложнее, а мотив неправедных желаний не выходит у него на первый план. Добавим, что в метерлинковском контексте оказывается значимым имя мальчика-волшебника Морис (Maurice), извлекающего любые предметы из книжной сумки и открывающего Далси иную реальность, мир грез. Кроме того, можно вспомнить о втором адресате повести Фолкнера - тяжело больной Маргарет Браун. В финале драмы Метерлинка Тильтиль дарит свою горлицу больной дочери соседки, и девочка исцеляется. Подарок Фолкнера Маргарет - своего рода жест Тильтиля, который должен принести если не исцеление, то облегчение страданий.

В повести Фолкнера можно найти отдельные образы и ситуации, восходящие к «Алисе в Стране чудес». Это прежде всего сам сон, местом действия которого, как пишет С. Прикетт, является «некий географический лимб» ${ }^{9}$. Кроме того, во время путешествия Далси вещи и человеческие тела меняют свои размеры. Морис придает любые размеры предметам, которые он извлекает из своей сумки. В одном из эпизодов Далси и ее спутники становятся крошечными и прячутся от нападающей на них сойки под шляпой. Другое дело, что эти приемы имеют у Фолкнера не игровую, а дидактическую основу. Дики уменьшается из-за своих неподобающе жестоких желаний, его спутники присоединяются к нему из сострадания.

9 Prickett, S. Victorian Fantasy. Waco (TX): Baylor University Press, 2005: 131. 
Главное отличие художественной системы «Дерева желаний» от «Алисы» - отсутствие сложной игровой рациональности Кэрролла, попыток раздробить привычный порядок и собрать его элементы в новую систему посредством словесной игры. Кэрроловские «приключения языка» здесь отсутствуют, нет пародии и парадокса. Это тем более интересно, если учесть обращение Фолкнера к детским образам в романах рубежа 1920-1930-х гг. и его изощренные модернистские попытки реконструировать детское сознание (прежде всего «Шум и ярость» и «Когда я умирала»). Фолкнер будет искать ключ к детскому сознанию совсем в другом поле, нащупывая сложный баланс интуитивного и рационального.

Повесть «Дерево желаний» отчасти иллюстрирует мнение Кимберли Рейнолдс: «...отношения между модернизмом и детской литературой противоречивы и запутаны... учитывая, с одной стороны, долг модернизма перед идеей ребенка и детской языковой игры, с другой (ошибочное) мнение о том, что модернистские игры с формой и сложные темы не могут найти место в литературе для детей» ${ }^{10}$. Однако в детской повести Фолкнера можно обнаружить отголоски модернистского языкового эксперимента, совсем не кэрроловского по форме и духу. Так, в речи Дики или взрослых «простецов» оживает внешняя форма слова, сохраняя означаемое смутным и непроясненным, порождая не нонсенс, но абсурд. Это могут быть неологизмы: "gillypus", "Mellomax" и др. Старик Эгберт вырезает из дерева неизвестное животное, наделяя его вымышленным именем, которое само служит оправданием его существования:

\author{
"What is it?" Dulcie asked. \\ "I don't know", the little old man answered. "I don't know what \\ it is, but I think it's a gillypus". \\ "What is a gillypus?" asked George. \\ "I don't know, but I expect it looks something like this". \\ "Why do you call it a gillypus, then, if you don't know what a \\ gillypus looks like?" \\ "Well", the little old man answered, "it looks more like a \\ gillypus than anything I ever saw" (25-26).
}

10 Цит. по: Westman, K. "Beyond Periodization: Children's Literature, Genre, and Remediating Literary History." Children's Literature Association Quaterly 32:4 (Winter 2007): 284 . 
«Джиллипас» в конце концов оживает; именно за причинение боли этому существу Дики наказан уменьшением. Нормальные размеры он обретает после того, как совершает добрый поступок - спасает джиллипаса в складках гигантской шляпы.

Уместно снова вспомнить название повести и обратиться к его, условно говоря, модернистскому измерению. Приключения детей разворачиваются в мире вербализованных желаний, оживающих слов. Акт вербализации способен наделять сущностью даже бессущностное. Так, когда Дики произносит фразу: "I want something to eat" (32), в его руках оказывается «нечто», "something" - съедобная, но не имеющая вкуса субстанция. Однако в большинстве своем желания не нейтральны, их молниеносное исполнение причиняет неудобство и даже страдания. Аллегория грехопадения уточняется: дети утрачивают контроль над миром, который постоянно и непредсказуемо разнимает на части и трансформирует их собственная речь. Речь - сила, которая оказывается тем более могущественной, чем слабее рациональный контроль. Хотя импульсивные высказывания принадлежат и старшим детям, и взрослым «простецам», источником высказываний, порождающих страдания или хаос, чаще других оказывается самый младший ребенок, слабо владеющий речью, коверкающий слова - брат Далси Дики (очевидный предшественник Бенджи Компсона). В полифонии голос Дики звучит на равных с более рациональными голосами, и наказывается Дики со всей строгостью, так же, как более взрослый Джордж, который поступает опрометчиво или действует назло.

Повесть «Дерево желаний» зачастую рассматривается как произведение, предвосхищающее отдельные темы романа «Шум и ярость» и новеллы «Когда наступает ночь» ${ }^{11}$. В обоих случаях можно обнаружить сходство и в системе персонажей: старшая сестра и маленький неразумный брат, мальчик-возмутитель спокойствия (Джордж очень напоминает Джейсона), темнокожая няня и ее муж. Конечно, «Шум и ярость» рождается не из единственного «образа девочки в запачканных штанишках» ${ }^{12}$, о котором Фолкнер так любил вспоминать в позднейших интервью и выступлениях. Джеймс Фергюссон считает Далси

11 См: Ditsky, J. William Faulkner's “The Wishing Tree”; Fergusson, J. Faulkner's Short Fiction. Knoxville, TN: University of Tennessee Press, 1991.

12 Например: Фолкнер в Виргинском университете (беседы со студентами и преподавателями) (1957-1958) / Пер. Ю. Палиевской // Фолкнер У. Статьи, речи, интервью, письма. М.: Радуга, 1985. С. 245; Фолкнер в Вест-Пойнте (1962) / Пер. В. Олейника // Там же. С. 393. 
одним из первых, «черновых» вариантов образа Кэдди ${ }^{13}$. Для нас важнее общность логики этих образов и их место в структуре произведения: Далси, подобно Кэдди, - «смелая девочка», благодаря которой становится возможным своеобразное откровение, пусть трагическое. Она «хозяйка» сна о дереве желаний, именно Далси в буквальном смысле открывает окно в иную реальность и отправляется в путешествие. Она же и Дульсинея (такова возможная полная форма ее имени), превозносимая «рыцарем»-автором.

Велик соблазн ограничиться интерпретацией повести «Дерево желаний» как текста, который «резонирует с концептуализацией детства» ${ }^{14}$ в романе «Шум и ярость», или как «черновика», в котором заявлены отдельные мотивы и темы романа 1929 года. Однако можно попытаться прочесть детскую повесть Фолкнера, обратившись к его ранним произведениям, написанным до главного романа конца 1920х. Определенные тематические параллели обнаруживаются с драмой «Марионетки» (1920), поэтическим сборником «Мраморный фавн» (1924), «Новоорлеанскими зарисовками» (1925), романами «Москиты» (1927) и «Флаги в пыли» (1927, в отредактированной версии - «Сарторис», 1929), новеллами 1920-х гг. Особый интерес, на наш взгляд, представляют переклички между детской повестью Фолкнера и другим полузабытым произведением середины 1920-х гг. - повестью «Майский день» (“Мayday”, 1926) ${ }^{15}$. Это тоже книга-подарок, правда, не ребенку, а взрослой возлюбленной.

Повесть «Майский день» была написана за год до «Дерева желаний». Единственная рукописная копия с иллюстрациями Фолкнера (три цветные акварели и два рисунка тушью в стиле Обри Бердсли) датирована 27 января 1926 г. и посвящена Хелен Бэйрд (Helen Baird). Фолкнер в это время ухаживал за Бэйрд; кроме повести, несколькими месяцами позже он посвятил ей рукописный поэтический сборник «Хелен: Ухаживание» (“Helen: A Courtship"); осенью того же года он заканчивает работу над романом «Москиты» и тоже посвящает его Хе-

13 См: Fergusson, J. Faulkner's Short Fiction: 27.

14 Godwin, H. “'Who Are You?': Modernism, Childhood, and Historical Consciousness in Faulkner's 'The Wishing Tree'." Faulkner and History (Faulkner and Yoknapatawpha, 2014), ed. by Jay Watson, James G. Thomas, Jr. Jackson, MS: University Press of Mississippi, 2017: 126.

15 Повесть издана на десять лет позже «Дерева желаний»: Faulkner, W. Mayday, introd. by Carvel Collins. London; Notre Dame: University of Notre Dame Press, 1977. 
$л^{16}{ }^{16}$. Ухаживание было неудачным, Хелен не разделяла чувства Фолкнера. Как замечает Карвел Коллинз, повесть «Майский день» должна была не только произвести впечатление на даму, но и «ослабить душевную боль» ${ }^{17}$ самого автора - неудачливого влюбленного.

Действительно, «Майский день» - очень необычное любовное послание; скорее, не романтический, а декадентский эпатирующий жест. Фолкнер описывает приключения рыцаря Гэлвина Артгильского, пережитые им в грезе-сновидении. Смущенный прекрасным образом, увиденным в темном водном потоке, Гэлвин проходит через поток, «не погрузившись в него» ${ }^{18}$, и пускается на поиски возлюбленной. Он соблазняет трех дам, предается эротическим утехам, возвращается в исходную точку своего путешествия, встречает святого Франциска Ассизского и совершает самоубийство, выбрав «смерть от воды». Таинственный образ, прельстивший Гэлвина, - «сестренка Смерть» (“little sister Death" ${ }^{19}$, именно ее он предпочитает всем земным женщинам. Нельзя не отметить очевидные пересечения со второй частью «Шума и ярости» (монолог Квентина), хотя подробно мы останавливаться на них не будем.

«Майский день» отсылает к обширному числу текстов, связанных с рыцарской темой: это не только «Смерть Артура» Томаса Мэлори, «Сэр Гавейн и Зеленый рыцарь» (с именем которого соотносится имя сэра Гэлвина ${ }^{20}$ ), «Дон Кихот», но и «артуровская» поэзия А.Ч. Суинберна. Однако в числе главных литературных подтекстов повести «Майский день» - популярные в 1920-е гг. пародийные рыцарские романы Джеймса Кейбелла, прежде всего «Юрген, Комедия справедливости» (Jurgen, A Comedy of Justice, 1919)21. Юрген, герой Кейбелла, движется от одной любовной интриги к другой, удовлетворяя все свои

16 Интересно, что в это время Эстелл уже всерьез готовится к разводу с Корнеллом Франклином.

17 Collins, C. "Introduction.” Faulkner W. Mayday: 18.

18 Faulkner, W. Mayday: 83.

19 Ibid.: 87.

20 Фолкнер, по всей вероятности, читал «Зеленого рыцаря» в прозаическом пересказе Дж. Л. Уэстон (1903) или в переводе Дж. Р. Р. Толкина и Э.В. Гордона (1925). Гэлвин, подобно Гавейну, формально терпит поражение, но обретает откровение и трагическую славу. Подробнее см.: Fulton, L. W. "William Faulkner's Southern Knights: 'Sir Gawain and the Green Knight', Sir Galwyn of Arthgyl, and Gavin Stevens.” Modern Philology 103:3 (2006): 358-384.

21 См.: Salda, M.N. "William Faulkner's Arthurian Tale: 'Mayday'." Arthuriana 4:4 (King Arthur in America) (Winter 1994): 348-375; Collins, C. "Introduction.” Faulkner W. Mayday: 3-41. 


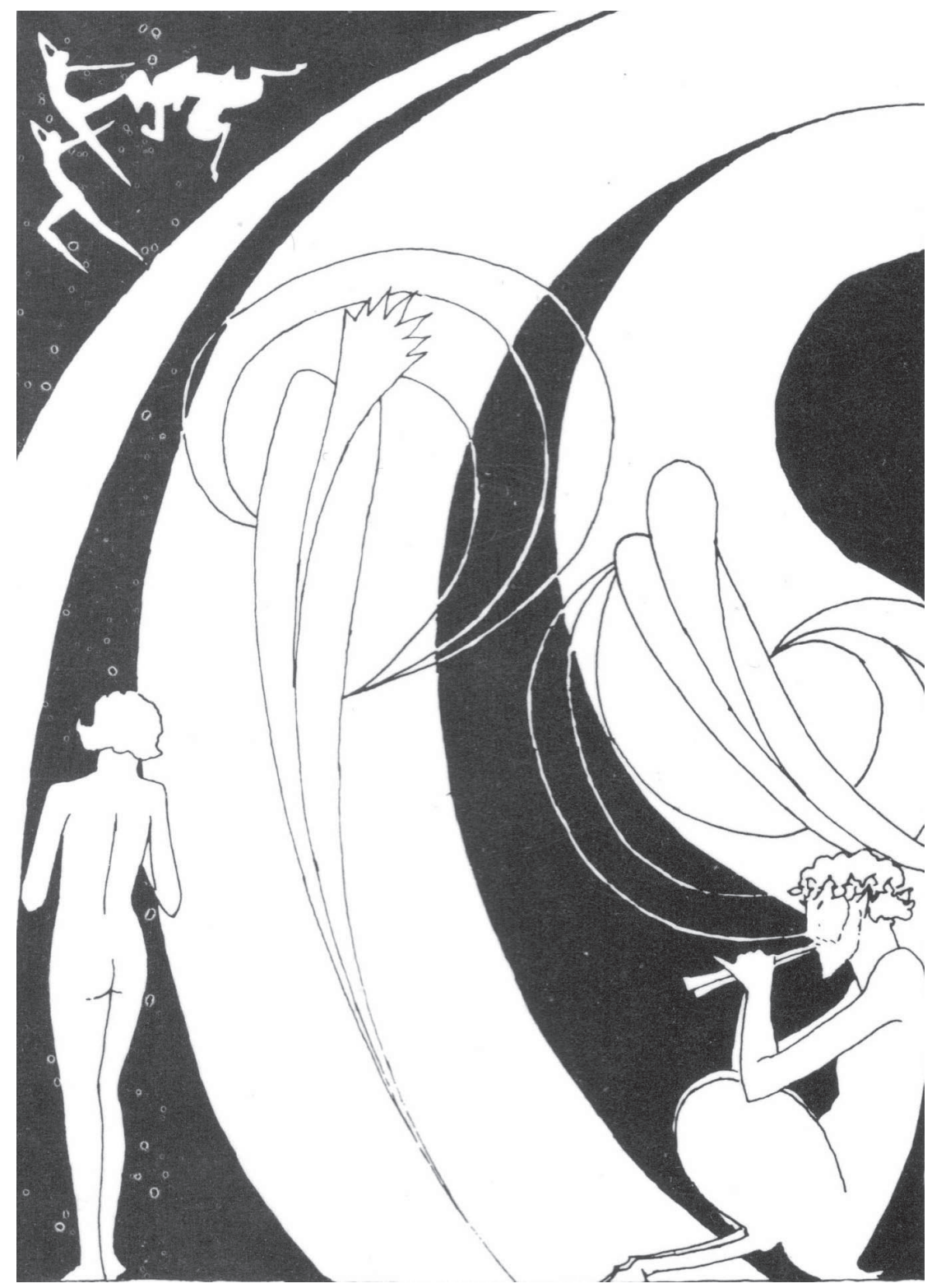

Иллюстрация У. Фолкнера к повести «Майский день» (титульный лист рукописной книги). 
духовные и плотские прихоти, и задается вопросом, который превращается в лейтмотив романа: «Чего же я все-таки желаю?» ("What thing is this which I desire?"22). Проблема желания - центральная для повести Фолкнера «Майский день». Гэлвин Артгильский в поисках неведомой возлюбленной приходит к выводу, что человек вожделеет не к объекту своего желания, но «К желанию вообще» ("it is not the thing itself that man wants, so much as the wanting of it") $)^{23}$.

Иллюстрация Фолкнера, открывающая повесть «Майский день», представляет собой графический эпиграф. Фолкнер обращается к сюжету «Послеполуденного отдыха фавна» Малларме: в нижней части фавн наигрывает на свирели, созерцая обнаженную красавицу; в левом верхнем углу он гонится за двумя нимфами, явившимися ему в поэтической реальности грезы. Сэр Гэлвин видит лик возлюбленной, вглядываясь в водоем, - это нарциссова греза, видение собственной души. Путь Гэлвина лежит через удовлетворение желаний и признание их избыточными и обременительными - к отказу от желаний и от жизни. «Дерево желаний», очевидно, наследует именно этот мотив отказа от желаний. В повести «Майский день» он определяет не только глубинный философский подтекст, но и эпатирующее воздействие необычного «любовного послания» на адресата-возлюбленную, и «самоисцеляющую» функцию произведения, которую отмечает Карвел Коллинз. В повести «Дерево желаний», предназначенной для дочери другой своей возлюбленной, Фолкнер транспонирует этот мотив, смягчая его и облекая его едва ли не в одежды христианской добродетели.

Образ, в котором Франциск Ассизский является сэру Гэлвину в финале «Майского дня», почти дословно совпадает с описанием Франциска в детской повести Фолкнера: это дерево с разноцветными листьями, на котором сидят птицы с оперением разных цветов. Дерево тоже стоит на берегу водоема (того самого, в котором сэр Гэлвин видел свою прекрасную даму). Как и в повести «Дерево желаний», в уста св. Франциску вложена проповедь: именно он предлагает Гэлвину выбор - вернуться в жизнь и вести существование тени, утратив самость и томясь желанием, или раствориться в потоке, слиться с ничто, оставшись собой до конца. Нарциссическая символика объединяется с переосмысленной символикой Грааля; повесть содержит несколько

22 Cabell, J.B. Jurgen, A Comedy of Justice. Online at http://www.gutenberg. org/cache/epub/8771/pg8771-images.html

23 Faulkner, W. Mayday: 71. 
отсылок к поэме Джеймса Рассела Лоуэлла «Видение сэра Лаунфаля»: иллюстрируя евангельскую максиму «где сокровище ваше, там будет и сердце ваше» (Мф. 6:22), Лаунфаль, совершая добродетельный поступок, обретает Чашу Грааля в собственном замке.

Последние слова св. Франциска в повести ("little sister Death") отсылают к «Гимну брату Солнцу»: «Тебе хвалу мою воздаю за сестру, телесную смерть, / Которой никто из живых избегнуть не может» ${ }^{24}$. Этот образ впервые появляется у Фолкнера в «Новоорлеанских зарисовках ${ }^{25}$; Квентин Компсон в «Шуме и ярости» вспоминает «добрейшего святого Франциска, называвшего смерть Маленькой Сестрой» ${ }^{26}$.

В повести «Дерево желаний» св. Франциск не говорит о сестре-смерти; путешествие Далси заканчивается благополучным возвращением домой. Хотя, возможно, образ умирающей Маргарет Браун, одной из двух девочек-адресатов повести, был для Фолкнера дополнительной рифмой к этому сюжету. Впрочем, образ реки, через которую путники проходят во имя откровения и освобождения от желаний, есть и здесь. Более того, подобно сэру Гэлвину (который проходит через поток, подаривший ему видение), Далси начинает свои приключения, пройдя через водную преграду - «поднимаясь в теплых водах сна» ("rising through the warm waters of sleep", 5). «Воды сна», «чаша сна» (“bowl of sleep", 5) - особая «оптика» грезы, «преломляющая» образ мира. Морис, проникнув в комнату Далси утром в день ее рождения, первым делом открывает окно: через стекло видны только мокрые деревья и дождь («теперь мы видим как бы сквозь тусклое стекло, гадательно», - 1 Кор. 13:12). Интересно, что через открытое окно нельзя сразу увидеть мир «лицом к лицу»: там обнаруживается «легкий туман, пахнущий глицинией» (8) - продолжение сна. Это не «тусклое стекло» обыденного зрения, но «линза» иной природы. За границей тумана начинается путешествие в поисках Дерева желаний. Однако откровение подразумевает не только новое зрение, но и слияние с реальностью грезы. В финале, чтобы вернуться домой и обрести синюю птицу, Далси и ее спутники погружаются в реку Святого

24 Франциск Ассизский. Гимн брату Солнцу / Пер. М. Шагинян. // Цветочки святого Франциска Ассизского. Первое житие святого Франциска. СПб.: Амфора, 2000. C. 336.

25 См.: Faulkner, W. “The Kid Learns (May 31, 1925).” In Faulkner, W. New Orleans Sketches. Jackson: University Press of Mississippi, 2009: 91.

26 Фолкнер У. Шум и ярость / Пер. О. Сороки // Фолкнер У. Собр. соч.: В 6 т. Т. 1. М.: Художественная литература, 1985. С. 385. 
Франциска, как в туман, внутри которого очертания предметов размыты и нечетки.

В мире, куда возвращается Далси, неправедным желаниям больше нет места. Интересно, что при поверхностном знакомстве с детской повестью откровение, полученное Далси, сводится к простому призыву заботиться о ближних и не быть эгоисткой. Дополнительные контексты творчества Фолкнера 1920-х годов делают этот моральный урок не столь однозначным.

\section{ЛИТЕРАТУРА:}

Фолкнер в Вест-Пойнте (1962) / Пер. В. Олейника // Фолкнер У. Статьи, речи, интервью, письма. М.: Радуга, 1985. С. 366-402.

Фолкнер в Виргинском университете (беседы со студентами и преподавателями) (1957-58) / Пер. Ю. Палиевской // Фолкнер У. Статьи, речи, интервью, письма. М.: Радуга, 1985. C. $245-361$.

Фолкнер У. Дерево, которое исполняет желания / Пер. с англ. И. Павлычевой. СПб.: Лицей, 2001.

Фолкнер У. Шум и ярость / Пер. с англ. О. Сороки // Фолкнер У. Собр. соч.: В 6 т. Т. 1. М.: Художественная литература, 1985.

Франциск Ассизский. Гимн брату Солнцу / Пер. М. Шагинян // Цветочки святого Франциска Ассизского; Первое житие святого Франциска. СПб.: Амфора, 2000. С. 335-336.

Brodsky, L.D. William Faulkner, Life Glimpses. Austin, TX: University of Texas Press, 1990.

Cabell, J.B. Jurgen, A Comedy of Justice. Online at http://www.gutenberg.org/cache/ epub/8771/pg8771-images.html

Ditsky, J. "William Faulkner's 'The Wishing Tree': Maturity's First Draft." The Lion and the Unicorn 2:1 (1978): 55-64.

Faulkner, W. "The Kid Learns (May 31, 1925).” In Faulkner W. New Orleans Sketches. Jackson: University Press of Mississippi, 2009: 86-91.

Faulkner, W. Mayday, introd. by Carvel Collins. London; Notre Dame: University of Notre Dame Press, 1977.

Faulkner, W. The Wishing Tree, ill. by Don Bolognese. New York: Random House, 1967.

Fergusson, J. Faulkner's Short Fiction. Knoxville, TN: University of Tennessee Press, 1991.

Fulton, L. W. "William Faulkner's Southern Knights: 'Sir Gawain and the Green Knight', Sir Galwyn of Arthgyl, and Gavin Stevens." Modern Philology 103:3 (2006): 358-384.

Godwin, H. "'Who Are You?': Modernism, Childhood, and Historical Consciousness in Faulkner's 'The Wishing Tree'." Faulkner and History (Faulkner and Yoknapatawpha, 2014), ed. by Jay Watson, James G. Thomas, Jr. Jackson: University Press of Mississippi, 2017: 122-133.

Prickett, S. Victorian Fantasy. Waco (TX): Baylor University Press, 2005.

Salda, M.N. "William Faulkner's Arthurian Tale: 'Mayday'." Arthuriana 4:4 (Winter 1994): 348-375.

Selected Letters of William Faulkner, ed. by Joseph Blotner. New York: Random House, 1976.

Westman, K. "Beyond Periodization: Children's Literature, Genre, and Remediating Literary History." Children's Literature Association Quaterly 32:4 (Winter 2007): 283-286. 


\section{REFERENCES}

Brodsky, L.D. William Faulkner, Life Glimpses. Austin, TX: University of Texas Press, 1990.

Cabell, J.B. Jurgen, A Comedy of Justice. Online at http://www.gutenberg.org/cache/ epub/8771/pg8771-images.html

Ditsky, J. "William Faulkner's 'The Wishing Tree': Maturity's First Draft." The Lion and the Unicorn 2:1 (1978): 55-64.

Faulkner, W . Derevo, kotoroe ispolniaet zhelaniia, [The Wishing Tree] transl. by I. Pavlycheva. St.-Petersburg.: Litsei Publ., 2001. (In Russ.)

Faulkner, W. "The Kid Learns (May 31, 1925).” Faulkner W. New Orleans Sketches. Jackson, MS: University Press of Mississippi, 2009: 86-91.

Faulkner, W. Mayday, introd. by Carvel Collins. London; Notre Dame: University of Notre Dame Press, 1977.

Faulkner, W. "Shum i iarost", ["The Sound and the Fury"] transl. by O. Soroka. In Faulkner, W. Sobranie sochineny: [Collected Works] in 6 vols. Vol. 1. Moscow: Khudozhestvennaia literatura Publ., 1985. (In Russ.)

"Faulkner v Vest-Pointe (1962)", ["Faulkner in West Point"] transl. by V. Oleinik. In Faulkner, W. Stat'i, rechi, interv'iu, pis'ma. [Essays, Speeches, Interviews, Letters] Moscow: Raduga Publ., 1985: 366-402. (In Russ.)

Faulkner v Virginskom universitete (besedy so studentami i prepodavateliami) (19571958), ["Faulkner at the University of Virginia"] transl. by Iu. Palievskaia. In Faulkner, W. Stat'i, rechi, interv'iu, pis'ma. [Essays, Speeches, Interviews, Letters] Moscow: Raduga Publ., 1985: $245-361$.

Faulkner, W. The Wishing Tree, ill. by Don Bolognese. New York: Random House, 1967.

Fergusson, J. Faulkner's Short Fiction. Knoxville, TN: University of Tennessee Press, 1991.

Francis of Assisi. "Gimn bratu Solntsu", ["Canticle of Brother Sun"] transl. by M. Shaginian. In Tsvetochki sviatogo Frantsiska Assizskogo. Pervoe zhitie sviatogo Frantsiska. [Little Flowers of St. Francis of Assisi. The First Hagiography of St. Francis] St.-Petersburg: Amfora Publ., 2000: 335-336. (In Russ.)

Fulton, L. W. "William Faulkner's Southern Knights: 'Sir Gawain and the Green Knight', Sir Galwyn of Arthgyl, and Gavin Stevens." Modern Philology 103:3 (2006): 358-384.

Godwin, H. "'Who Are You?': Modernism, Childhood, and Historical Consciousness in Faulkner's 'The Wishing Tree'." Faulkner and History (Faulkner and Yoknapatawpha, 2014), ed. by Jay Watson, James G. Thomas, Jr. Jackson, MS: University Press of Mississippi, 2017: 122-133.

Prickett, S. Victorian Fantasy. Waco (TX): Baylor University Press, 2005.

Salda, M.N. "William Faulkner's Arthurian Tale: 'Mayday'." Arthuriana 4:4 (Winter 1994): 348-375.

Selected Letters of William Faulkner, ed. by Joseph Blotner. New York: Random House, 1976.

Westman, K. "Beyond Periodization: Children's Literature, Genre, and Remediating Literary History.” Children's Literature Association Quaterly 32:4 (Winter 2007): 283-286. 